\title{
Study of Serological Parameters in Thalassemic Patients of GMC Jammu
}

\author{
Dr. Suby Singh ${ }^{1}$, Dr. Ravinder Singh ${ }^{2}$, Dr. Kuldeep K Kaul ${ }^{3}$, \\ Dr. Mandeep Kour ${ }^{4}$. \\ ${ }^{I}$ Resident, Department Of Pathology, Govt. Medical College, Jammu, J\&K. \\ ${ }^{2}$ Registrar, Department Of Surgery, Govt. Medical College, Jammu, J\&K. \\ ${ }^{3}$ HOD, Department Of Pathology, Govt. Medical College, Jammu. J\&K. \\ ${ }^{4}$ Assistant Professor, Department Of Oral Pathology and Microbiology, \\ Indira Gandhi Govt. Dental College, Jammu. J\&K.
}

\begin{abstract}
Objectives:

- To study serological parameters in thalassemic patients.

- To correlate various parameters in these patients.

- To study the effect of regular safe blood transfusion \& adequate iron chelation on these parameters.

- To identify parameters of prognostic significance in these patients.

Material and Methods:

The present study was conducted in the Post-Graduate Department of Pathology in collaboration with department of biochemistry, Government Medical College, Jammu. This institution is a tertiary care centre of the entire Jammu province of Jammu and Kashmir state where in addition to our own state, patients from adjoining areas of Punjab and Himachal Pradesh come to seek medical attention. Proper consent was obtained from the patients after explaining the patients and their parents the nature and type of study.
\end{abstract}

\section{Introduction}

The thalassemias are a group of congenital anemias that have in common deficient (reduced or absent) synthesis of one or more of the globin subunits of the normal human hemoglobins. This results in excess production of the other chain which damages the red cell membrane and begins with cascade that ends with significant morbidity and mortality. They are inherited autosomal recessive disorders. The thalassemias are the commonest monogenic diseases in man The condition forms a part of the spectrum of diseases known collectively as hemoglobinopathies, which can be classified broadly into two types. The first subdivision consists of conditions involving qualitative disorders of $\mathrm{Hb}$ such as sickle cell anemia, that result from an inherited structural alteration in one of the globin chains. The second major subdivision of the hemoglobinopathies constitute the thalassemias.

The primary defect is usually quantitative but there are mutations resulting in structural variants produced at reduced rate (i.e. HbE, Hb Lepore) and mutations producing hyperunstable hemoglobin variants with a thalassemia phenotype (thalassemic hemoglobinopathies). Therefore, a rigid differentiation from the qualitative changes of hemoglobin structure that characterize the hemoglobinopathies is no longer appropriate.

According to the chain whose synthesis is impaired, the thalassemias are called $\alpha-, \beta-, \gamma-, \delta-, \delta \beta-$, or $\in \gamma \delta \beta$-thalassemias. These subgroups have in common an imbalanced globin synthesis, with the consequence that the globin produced in excess is responsible for ineffective erythropoeisis (intramedullary destruction of erythroid precursors) and hemolysis (peripheral destruction of red cells). For a better understanding of this disease one must know the importance of hemoglobin. Human hemoglobin is heterogenous at all stages of development. Different hemoglobins are synthesised in the embryo, fetus and adult, each adapted to the particular oxygen requirement. In vertebrates, haemoglobin $(\mathrm{HbA})$ is the iron containing oxygen transport protein that is found in red blood cells which carries oxygen from the lungs to the rest of the body and then brings the carbon dioxide back to the lungs to be dispensed. People who have thalassemia produce fewer healthy hemoglobin proteins and their bone marrow produces fewer healthy red blood cells. With too few normal red blood cells, not enough hemoglobin is available to help carry oxygen to the body. Hemoglobin exists in various forms differing in structure of globin chain only, whereas haem portion is same in all types of haemoglobin.

Haemoglobin A ( $\mathrm{HbA})$ consists of two globin $\alpha$-chains and two globin $\beta$-chains which contains 141 and 146 amino acids respectively. They are assembled each with an associated heme group into a tetrameric molecule with the formula $\alpha_{2} \beta_{2}$. It is the predominant hemoglobin found in adults with a normal amount of over 95\%. 'Hemoglobin $\mathrm{F}(\mathrm{HbF})$ consists of two globin $\alpha$-chains and two globin gamma-chains. This is found in foetuses and newborns. It is replaced by adult haemoglobin at about approximately 6 months of age. In adults it 
is $0.2-1 \%$. Hemoglobin $\mathrm{A}_{2}\left(\mathrm{HbA}_{2}\right)$ consists of two globin $\alpha$-chains and two globin delta chains. It is a normally present in adults in small amounts $(2-3.3 \%)$.

Hemoglobin is a conjugated protein of molecular weight $64,000 \mathrm{KD}$ and consists of an iron containing portion, the haem, and a protein portion called globin. The $\alpha$ globin gene clusters are present on chromosome 16 while the $\beta$ gene clusters are present on chromosome 11 .

Thalassemia syndromes result from a large series of molecular defects, which alter the expression of one or more globin genes. They are classified into three types:

1. $\square$ thalassemialt is the most common single gene disorder in our country They refer to that group of inherited hemoglobin disorder which are characterized by reduced synthesis $\left(\beta^{+}\right.$thalassemia) or absence ( $\beta^{\circ}$ thalassemia) of $\beta$-globin chain production which causes anemia.

2. thalassemiaThere is defect in the synthesis of $\alpha$ chains. This manifests in both foetal and adult lives. It has main three clinical forms- Hemoglobin Bart's hydrops foetalis syndrome, haemoglobin $\mathrm{H}$ disease and $\alpha$ thalassemia carrier state.

3. Miscellaneous Thalassemic syndromes- These occur because of multiple combinations of $\beta, \alpha$ gene with other structurally abnormal hemoglobins like $\mathrm{Hb} \mathrm{D}, \mathrm{Hb} \mathrm{S}$ and $\mathrm{Hb} \mathrm{E}$.

\section{Inclusion Criteria}

The study was conducted on all diagnosed cases of thalassemia registered with J\&K state thalassemia welfare society attending thalassemia day care center at SMGS Hospital, GMC Jammu.

\section{Exclusion Criteria}

- Patients coming irregularly for transfusion

- Patients with incomplete records

- Patients with inadequate sample

Patients were studied prospectively for one year that is from november 2014 to october 2015. A total of 273 patients are registered with $\mathrm{J} \& \mathrm{~K}$ thalassemia welfare society but 100 patients could be taken up for study as some were excluded due to sample inadequacy, incomplete records and some were irregular in attending the thalassemia clinic. Clinical details and demographic data (age, sex, socioeconomic status) was gathered from the records available at the day care centre. Other relevant details were collected from the patients and their attendants. Clinical details included history regarding blood transfusions (number of transfusions/month, whether regular/irregular), chelation therapy (adequacy, nature of therapy, side effects), vaccination history, history of jaundice or any blood transfusion related complication.

About $5 \mathrm{ml}$ of venous sample was withdrawn from the patients. under all aseptic precautions with informed consent and subjected to various investigations.

\section{The serological investigations comprised of following tests:}

- Serum ferritin was estimated by the architect ferritin assay which is a chemiluminescent microparticle immunoassay (CMIA) for the quantitative determination of ferritin in human serum and plasma. It is a two step immunoassay using CMIA technology with flexible assay protocols, reffered to as chemiflex.

- In the first step, sample and anti-ferritin coated paramagnetic microparticles are combined. Ferritin present in the sample binds to the anti-ferritin coated microparticles. After washing, anti-ferritin acridinium labelled conjugate is added in the second step. Pre-trigger solutions \{containing $1.32 \%(\mathrm{w} / \mathrm{v})$ hydrogen peroxide\} and trigger solutions (containing $0.35 \mathrm{~N}$ sodium hydroxide) are then added to the reaction mixture; the resulting chemiluminescent reaction is measured as relative light units (RLUs). A direct relationship exists between the amount of ferritn in the sample and the RLUs detected by the architect i optical system.

- Specimens with a ferritin value exceeding $2000 \mathrm{ng} / \mathrm{ml}$ are flagged with the code ">2000" and may be diluted with either the automated dilution protocol or the manual dilution procedure.

- By using the automated dilution protocol, the system performs a 1:20 dilution of the specimen. The system will use the dilution factor to automatically calculate the concentration of the sample before dilution which is the reported result.

- For manual dilutions the suggested dilution is 1:20. For a 1:20 dilution, add $20 \mu \mathrm{l}$ of the patient's sample to $380 \mu 1$ of architect i multi-assay manual diluent.

- The operator enters the dilution factor in the patient or control order screen. The system uses this dilution factor to automatically calculate the concentration of the sample before dilution which is the reported result. The dilution is performed so that the diluted result reads greater than $80 \mathrm{ng} / \mathrm{ml}$. If the diluted result reads less than $80 \mathrm{ng} / \mathrm{ml}$, the sample is retested undiluted.

- Other iron studies like serum iron and total iron binding capacity were also done using automated analyzer. 
- The serum sample is automatically mixed with a ferric solution, which saturates all available iron binding sites of transferrin. Under non-acidic conditions ( $\mathrm{pH} \mathrm{8.6),} \mathrm{only} \mathrm{unbound,} \mathrm{excess} \mathrm{saturating} \mathrm{iron} \mathrm{is} \mathrm{available}$ to be reduced to ferrous iron by ascorbic acid and to form a blue complex with ferene. Subsequent addition of acid (4.5) releases the iron bound to transferrin; this additional iron is reduced to ferrous iron by ascorbic acid and forms an increased amount of blue complex with ferene. The increase in absorbance upon shifting of $\mathrm{pH} 8.6$ to 4.5 , measured using a bichromatic $(600,700 \mathrm{~nm})$ end point technique, is proportional to the concentration of transferrin bound iron, and thus to the iron binding capacity of the serum sample.

- Liver function tests especially SGPT, SGOT, $\gamma$ GT, serum alkaline phosphatase were done using automated analyzer. In addition serum bilirubin, serum total proteins, serum albumin estimation was also done.

- Serum urea and serum creatinine estimation was done on Architect system using enzymatic methods.

- Analyzers are highly automated to improve user safety from biohazards, and to diminish the risk of crosscontamination. A probe measures an aliquot of sample and places it into a reaction vessel. Reagents are added from an on-board refrigerated supply. The sample is mixed with the appropriate reagent to produce a reaction that results in a color. Incubation time is allowed and then photometric testing determines the concentration of analyte.The concentration of the analyte determines the strength of color produced. The photometer shines light of the appropriate wavelength at the sample and measures the amount of light absorbed, which is directly correlated to the concentration of the analyte in the sample. Results were displayed on screen or sent to a printer and the results were printed.

For analyses of liver function tests and renal function tests samples were loaded into the machine and tests were programmed by the user.

- Blood sugar estimation was done by automated analyser using hexokinase method. The hexokinase method is a reference method for determination of glucose concentration. The method is specific for D-glucose. Under the action of the hexokinase enzyme, D-glucose is phosphorylated with ATP molecule to form glucose -6-phosphate. By the action of glucose-6-phosphate dehydrogenase (G-6-PDH) in the presence of NADP, thus formed glucose-6-phosphate transforms to 6-phosphogluconate, whereby NADPH is formed. The absorbance of NADPH is measured in the UV region (334, 340 or $365 \mathrm{~nm}$ ). The system measures the resulting absorbance readings, calculates the absorbance difference and then converts the absorbance difference into reported units.

- Blood grouping that was done by ID gel card method.

\section{Requirements:}

1. Microtubes containing sephadex gel prepared in a buffer such as LISS (low ionic strength saline) or saline are available. In the cards used for blood grouping, red cell specific antisera and a preservative are also added to the gel at the time of manufacture. Each card contains six such microtubes. ID-Card "Diaclon ABO/D + reverse typing cards" containing monoclonal anti-A, anti-B and anti-D within the gel matrix. The microtube control is the negative control. Two microtubes with neutral gel serve for reverse grouping with A \& B cells.

2. ID-Diluent 2(modified low ionic strength saline)

3. Test cell reagents- ID Diacell A \& B, O in a $0.8 \% \pm 0.1 \%$ suspension. This is available in $10 \mathrm{ml}$ vials which are ready to use.

4. 1D-Dispenser

5. ID-Pipetor and tips

6. ID-Working Table

7. ID-Centrifuge

\section{Sample}

A $5 \%$ red cell suspension is prepared by adding $0.5 \mathrm{ml}$ of Diluent 2 to $50 \mu \mathrm{l}$ of whole blood and mixed gently.

\section{Procedure}

1. The ID-Card with unique patient/donor number is identified.

2. Aluminum foil from first 4 microtubes is removed for $\mathrm{ABO}$ grouping by holding the ID card in upright position.

3. 10 or $12.5 \mu \mathrm{l}$ of patient's red cell suspension is pipetted to microtubes $1-4$ (A,B,D,ctrl)

4. Then it is incubated at room temperature for $10 \mathrm{~min}$

5. The ID Cards are centrifuged for 10 mins in the ID Centrifuge.

6. Results were read and recorded.

\section{Interpretation}

Positive: agglutinated cells formed a red cell line on the surface of gel or agglutinates dispersed in gel 
Negative: compact button of cells on the bottom of the microtube. Other investigation included routine urine examination.

Data was analysed using statistical software MS-Excel and SPSS for windows. Data reported as mean (SD) and proportions as deemed appropriate for quantitative and qualitative variables respectively.

Correlation between serum ferritin and SGPT and other parameters were evaluated using Pearson correlation coefficient (r). Point biserial values are reported wherever correlation with dichotomous variables (hepatitis and liver enzymes) are evaluated. A p-value of $<0.05$ is considered statistically significant. All pvalues are 2-tailed.

\section{Results}

The present study was prospective in nature and was carried out in the Postgraduate Department of Pathology, Government Medical College, Jammu in collaboration with the department of biochemistry over a period of one year w.e.f. November 2014 to October 2015. This study was approved by IEC. Proper consent was obtained after explaining the patients and their parents the nature and type of study. 100 thalassemia patients were studied during the course of one year.

Following observations were made:

Table 1:

Distribution of thalassemia patients according to clinical severity

\begin{tabular}{|l|c|c|}
\hline Type of thalassemia & No of patients & Percentage (\%) \\
\hline Thalassemia Major & 90 & 90 \\
\hline Thalassemia Intermedia & 10 & 10 \\
\hline Thalassemia minor & 0 & 0 \\
\hline
\end{tabular}

The present study comprised of 90 thalassemia major patients and 10 thalassemia intermedia patients.Though 6 thalassemia minor patients were registered with the thalassemia welfare society but were not included in the study as they were not attending the thalassemia clinic because of non requirement of transfusions.

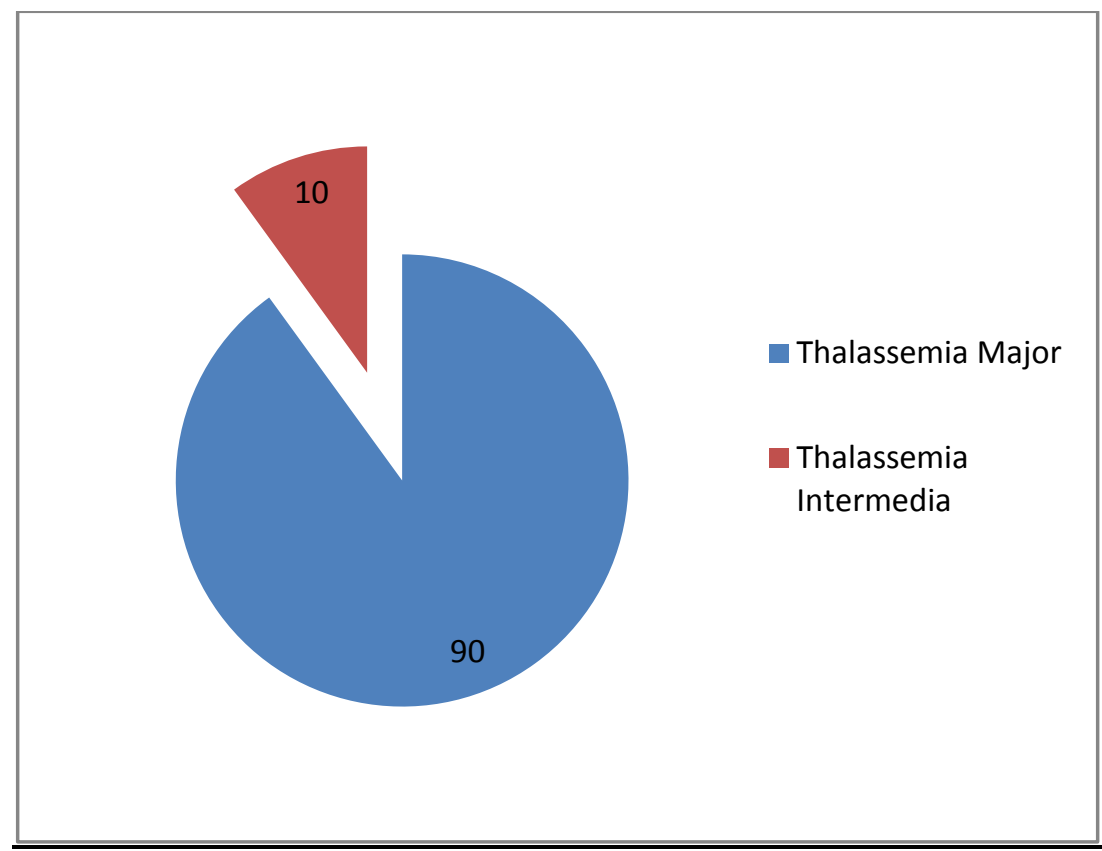

Graph 1: Distribution of thalassemia patients according to clinical severity

Table 2:

Age wise distribution of thalassemia patients

\begin{tabular}{|l|c|c|}
\hline Age group(years) & No of patients & Percentage(\%) \\
\hline $1-5$ & 12 & 12 \\
\hline $6-10$ & 40 & 40 \\
\hline $11-15$ & 25 & 25 \\
\hline$>15$ & 23 & 23 \\
\hline Total & 100 & 100 \\
\hline
\end{tabular}


In the present study majority of the patients (40\%) were in the age group of 6-10 years followed by $25 \%$ in the age group of $11-15$ years. $23 \%$ of the patients were above the age of 15 years. Only $12 \%$ of the patients were in the age group of 1-5 years. The youngest patient was 2 years old and oldest was 31 years old. The mean age was $11.85 \pm 6.3$ years.

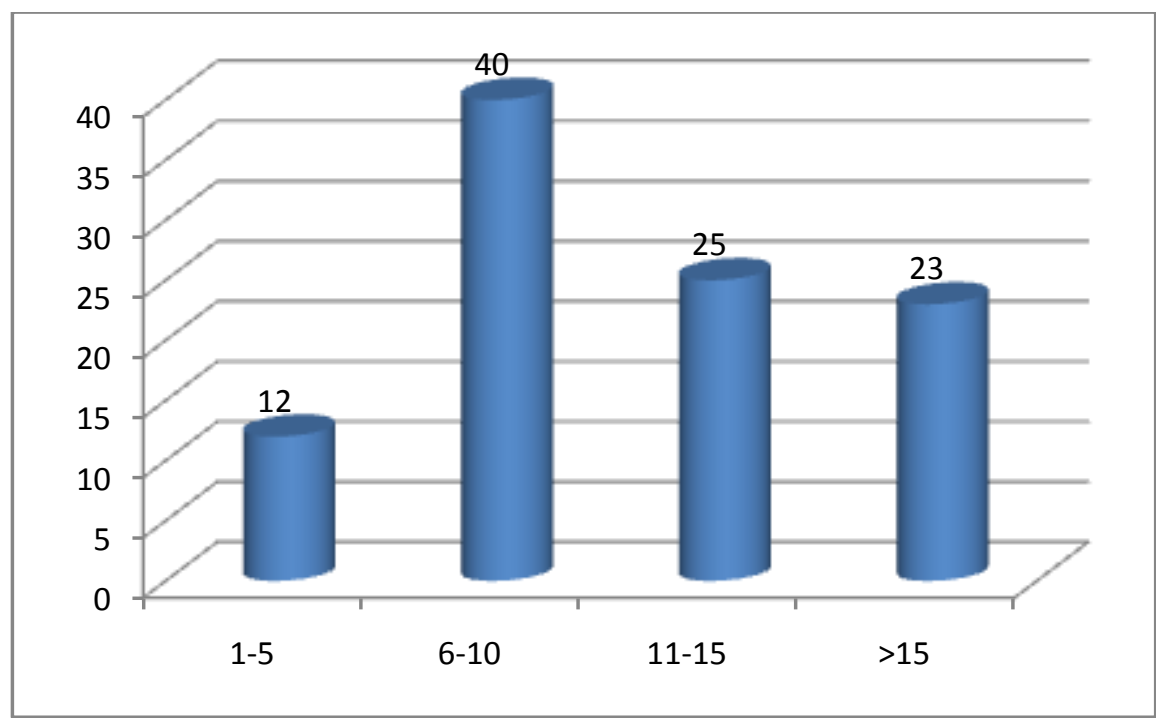

Graph 2 Age wise distribution of thalassemia patients

Table 3: Sex distribution of thalassemia patients

\begin{tabular}{|l|l|l|}
\hline Sex & No. of patients & Percentage $(\%)$ \\
\hline Male & 62 & 62 \\
\hline Female & 38 & 38 \\
\hline Total & 100 & 100 \\
\hline
\end{tabular}

Males were more in number comprising of $62 \%$ of patients and females were $38 \%$.

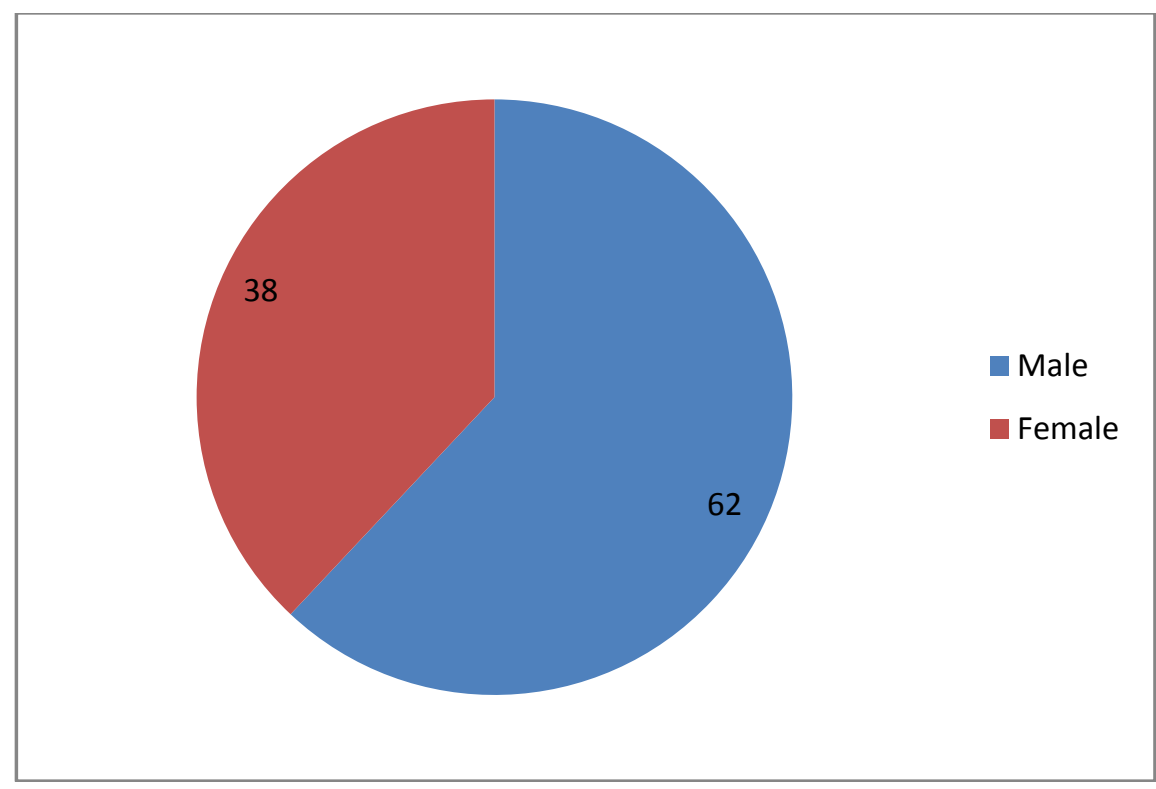

Graph 3: Sex distribution of thalassemia patients

Table 4: Spleen status of thalassemia patients

\begin{tabular}{|l|c|c|}
\hline Spleen status & No. of patients & Percentage(\%) \\
\hline Enlarged & 50 & 50 \\
\hline
\end{tabular}




\begin{tabular}{|l|c|c|}
\hline Normal & 41 & 41 \\
\hline Splenectomy & 9 & 9 \\
\hline Total & 100 & 100 \\
\hline
\end{tabular}

Fifty patients had splenomegaly at the time of study. Out of these 50 patients, 14 had mild splenomegaly, 34 had moderate splenomegaly and 2 had massive splenomegaly. Nine patients had already undergone splenectomy at the time of study and rest 40 patients had normal spleen.

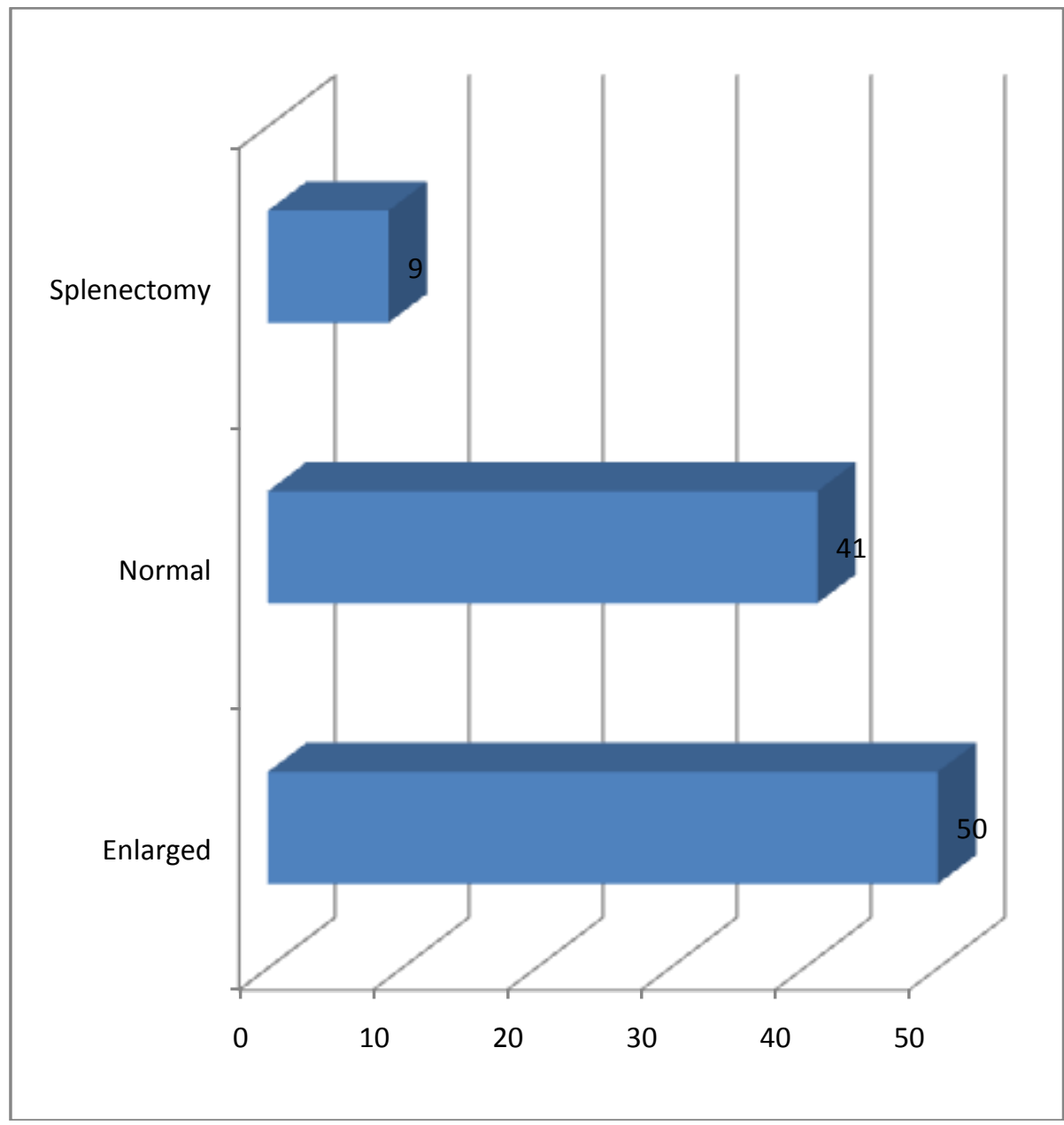

Graph 4: Spleen status of thalassemia patients

Table 5: Blood transfusions received by thalassemia patients

\begin{tabular}{|l|c|c|}
\hline Blood transfusions & No. of patients & Percentage(\%) \\
\hline$<100$ & 40 & 40 \\
\hline $100-200$ & 27 & 27 \\
\hline $201-300$ & 17 & 17 \\
\hline $301-400$ & 2 & 2 \\
\hline $401-500$ & 7 & 7 \\
\hline $501-600$ & 3 & 3 \\
\hline$>600$ & 4 & 4 \\
\hline Total & 100 & 100 \\
\hline
\end{tabular}

Packed red blood cells were received by the patients. Minimum number of blood transfusions received by a patient was 10 and the maximum number of transfusions received was $979.40 \%$ of the patients received less than 100 transfusions. $44 \%$ of the patients have received 100-300 transfusions. $16 \%$ of the patients have received above 300 transfusions. Only $25 \%$ of the patients were receiving regular blood transfusions (23/month). The mean and S.D. was calculated to be $193.4 \pm 176.6$. 


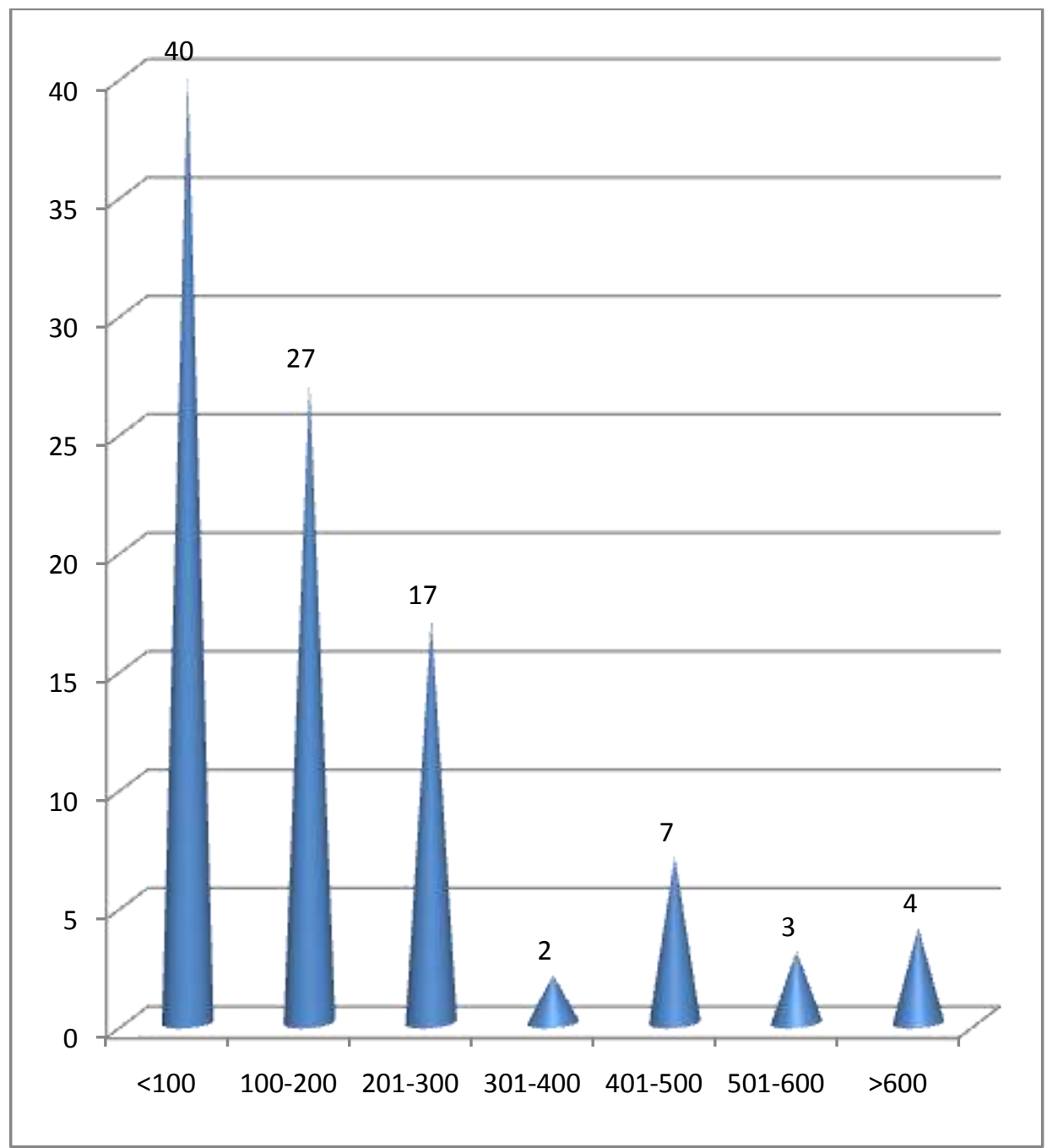

Graph 5: Blood transfusions received by thalassemia patients

Table 6: Distribution of $\mathrm{ABO}$ and Rh blood groups in thalassemia patients

\begin{tabular}{|l|c|c|}
\hline Blood groups & No of patients & Percentage(\%) \\
\hline $\mathrm{A}+$ & 27 & 27 \\
\hline $\mathrm{AB}+$ & 13 & 13 \\
\hline $\mathrm{B}+$ & 26 & 26 \\
\hline $\mathrm{O}+$ & 29 & 29 \\
\hline $\mathrm{A}-$ & 1 & 1 \\
\hline $\mathrm{AB}-$ & 1 & 1 \\
\hline $\mathrm{B}-$ & 1 & 1 \\
\hline O- & 2 & 2 \\
\hline Total & 100 & 100 \\
\hline
\end{tabular}

Blood group O+ was found to be most frequent (29\%) followed by A+ group (27\%) and B+ group (26\%). Rh negative blood groups were the least frequent comprising $5 \%$ of the total thalassemic patients in the study of which 1 patient each was included in the A-, AB- and B- group. 2 patients were having O- blood group. In thalassemia intermedia patients blood group were arranged in descending order as $A+>O+>B>A B+$ comprising 4, 3, 2\& 1 patient respectively None of the patient had Rh negative blood group. Among males most frequent blood group was $\mathrm{O}+$ followed by $\mathrm{A}+\mathrm{B}+$ and $\mathrm{AB}+$ blood group comprising 21,19, 17 and 3 patients respectively. 2 patients were having $\mathrm{O}$ - blood group. Among females blood group were arranged in descending order as $\mathrm{B}+>\mathrm{A}+>\mathrm{O}+=\mathrm{AB}+$ comprising $10,9,8 \& 8$ patients respectively. Rh- blood group was foumd in 3 patients that were A-, B- and $\mathrm{AB}-$. 


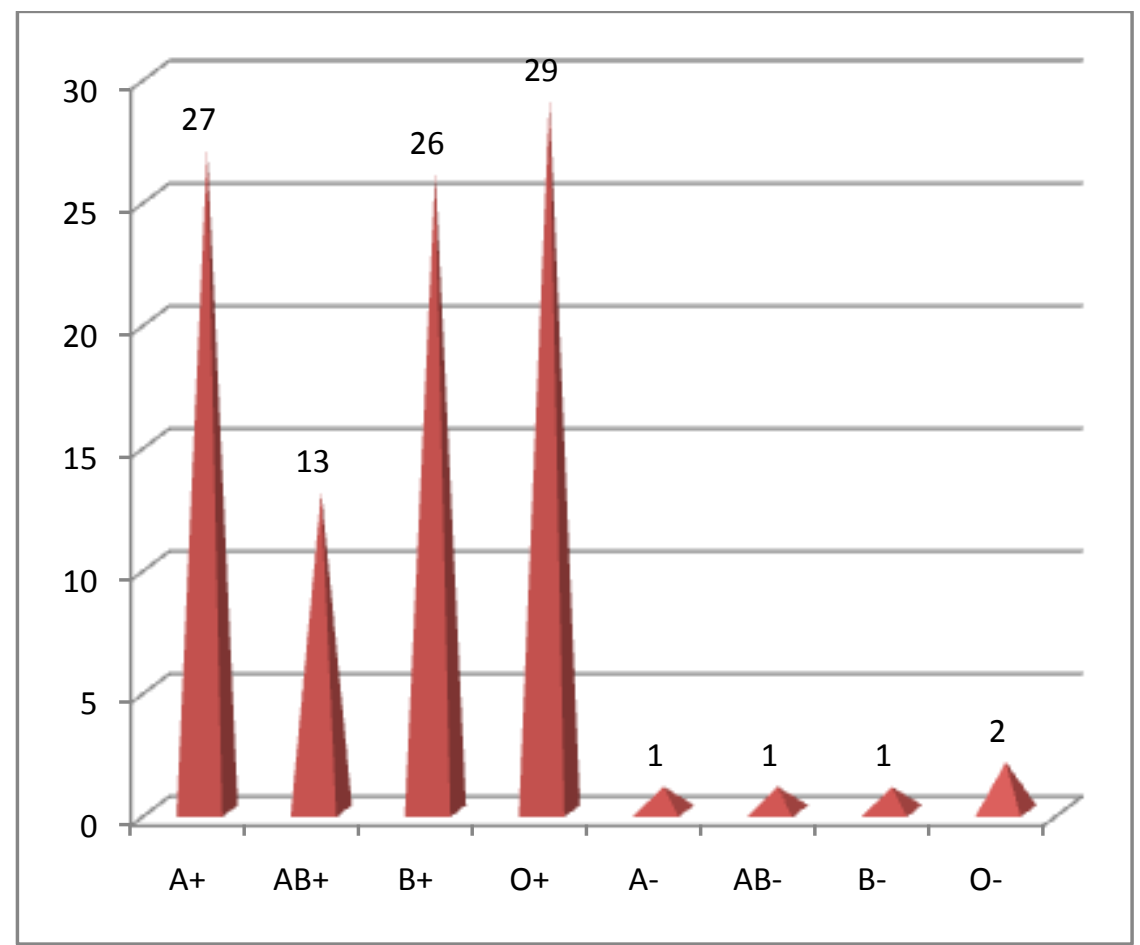

Graph 6: Distribution of $\mathrm{ABO}$ and Rh blood groups in thalassemia patients

Table 7: Hepatitis status of thalassemia patients

\begin{tabular}{|l|c|c|}
\hline Hepatitis status & No of patients & Percentage(\%) \\
\hline HCV+ & 12 & 12 \\
\hline HBsAg+ & 1 & 1 \\
\hline Total & 13 & 13 \\
\hline
\end{tabular}

A total of 12 patients were positive for anti- hepatitis $\mathrm{C}$ antibodies and only one patient was found to be positive for hepatitis B surface antigen. In total $13 \%$ of the individuals were hepatitis positive.

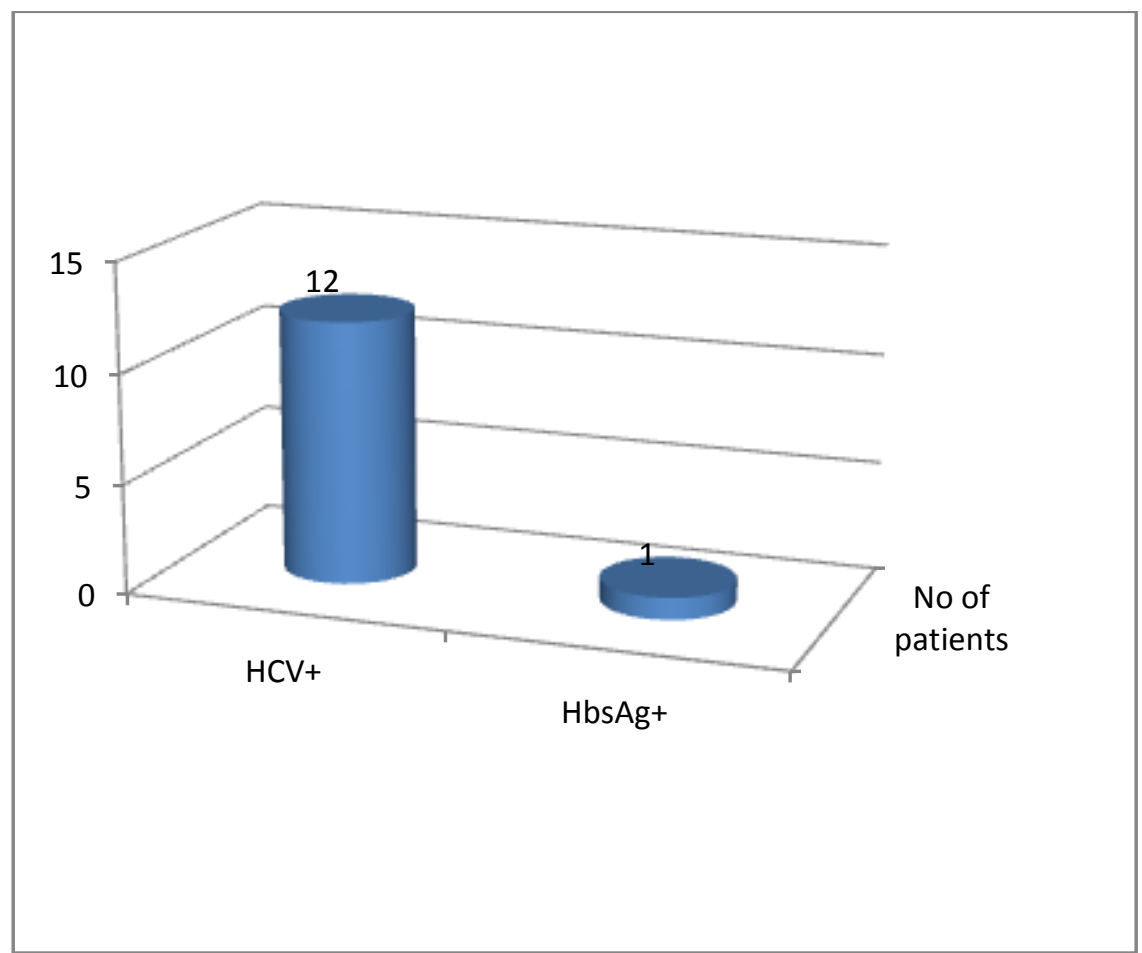

Graph 7: Hepatitis status of thalassemia patients 
Table 8: Serum Ferritin of thalassemia patients

\begin{tabular}{|l|c|c|}
\hline Serum ferritin(ng/ml) & No. of patients & Percentage(\%) \\
\hline$<1000$ & 3 & 3 \\
\hline $1000-2000$ & 11 & 11 \\
\hline $2001-3000$ & 28 & 28 \\
\hline $3001-4000$ & 18 & 18 \\
\hline $4001-5000$ & 8 & 8 \\
\hline $5001-6000$ & 14 & 14 \\
\hline $6001-7000$ & 5 & 5 \\
\hline $7001-8000$ & 5 & 5 \\
\hline $8001-9000$ & 2 & 2 \\
\hline $9001-10,000$ & 5 & 5 \\
\hline$>10,000$ & 1 & 1 \\
\hline Total & 100 & 100 \\
\hline
\end{tabular}

Majority (28\%) of the patients had ferritin value between $2001 \mathrm{ng} / \mathrm{ml}-3000 \mathrm{ng} / \mathrm{ml}$. The ferritin values ranged from 481.98 to $12,000 \mathrm{ng} / \mathrm{ml}$. Only 1 patients had ferritin value greater than 10,000 that was 12,000 $\mathrm{ng} / \mathrm{ml} .3$ patients had values less than $1000 \mathrm{ng} / \mathrm{ml}$ with values $481.98,679.27$ and $791.3 \mathrm{ng} / \mathrm{ml}$ respectively. The mean and S.D. was observed to be $4160 \pm 2426 \mathrm{ng} / \mathrm{ml}$.

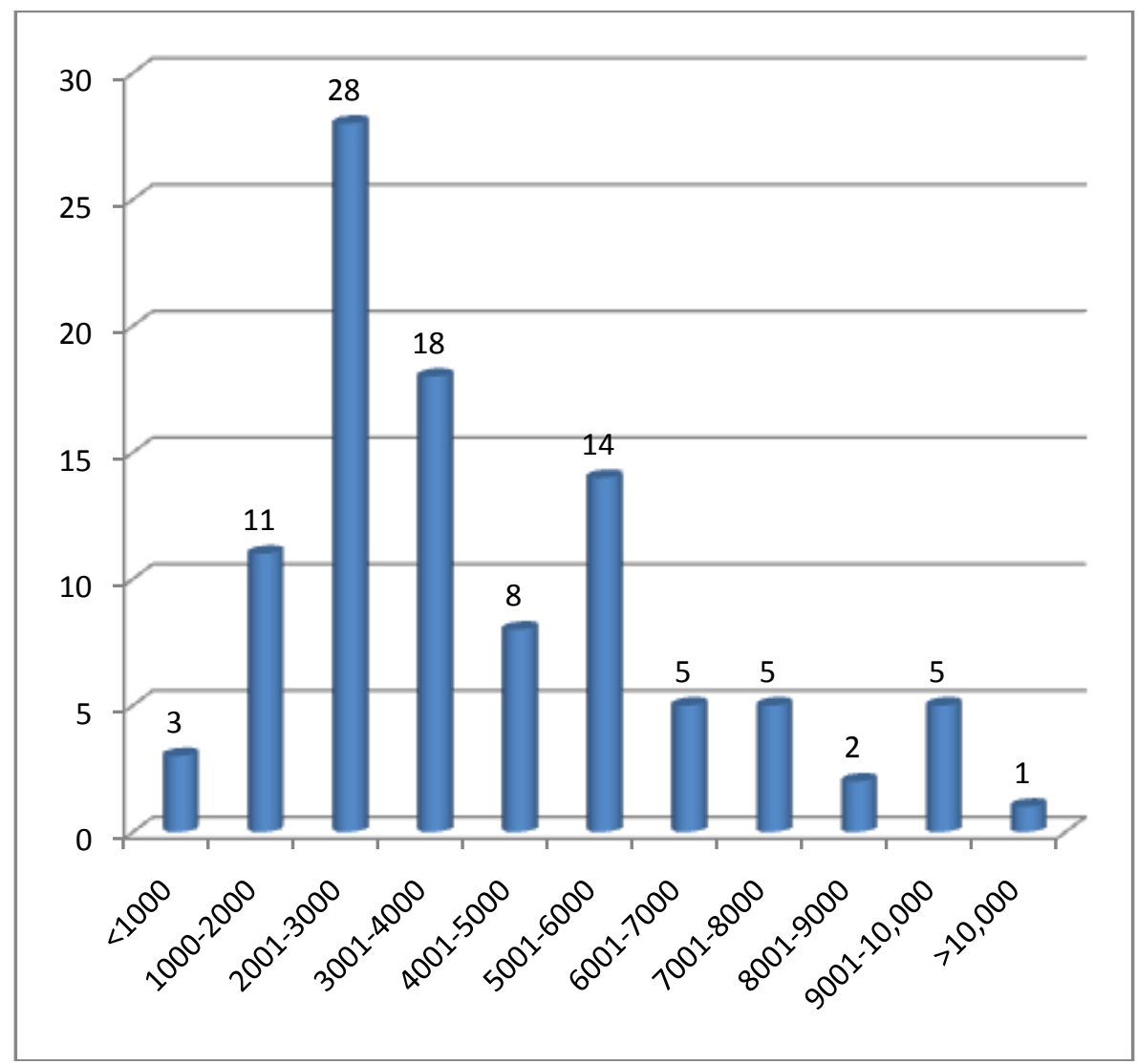

Graph 8: Serum Ferritin of thalassemia patients

Table 9: Liver Function Tests in thalassemia patients

\begin{tabular}{|l|l|l|l|l|}
\hline & SGOT & SGPT & ALP & GGT \\
\hline No. of patients with normal value & 20 & 55 & 13 & 86 \\
\hline No of patients with Increased value & 80 & 45 & 87 & 14 \\
\hline
\end{tabular}

SGOT, SGPT, ALP and GGT were increased in 80,45,87 and 14 patients respectively but significant increase was considered in patients having two times increase in the upper limit of the reference range. Significantly elevated levels of SGOT,SGPT and ALP were seen in 34, 19 and 9 patients respectively. None of these patients had significantly increased GGT values except one with GGT value of 166 IU/L. 


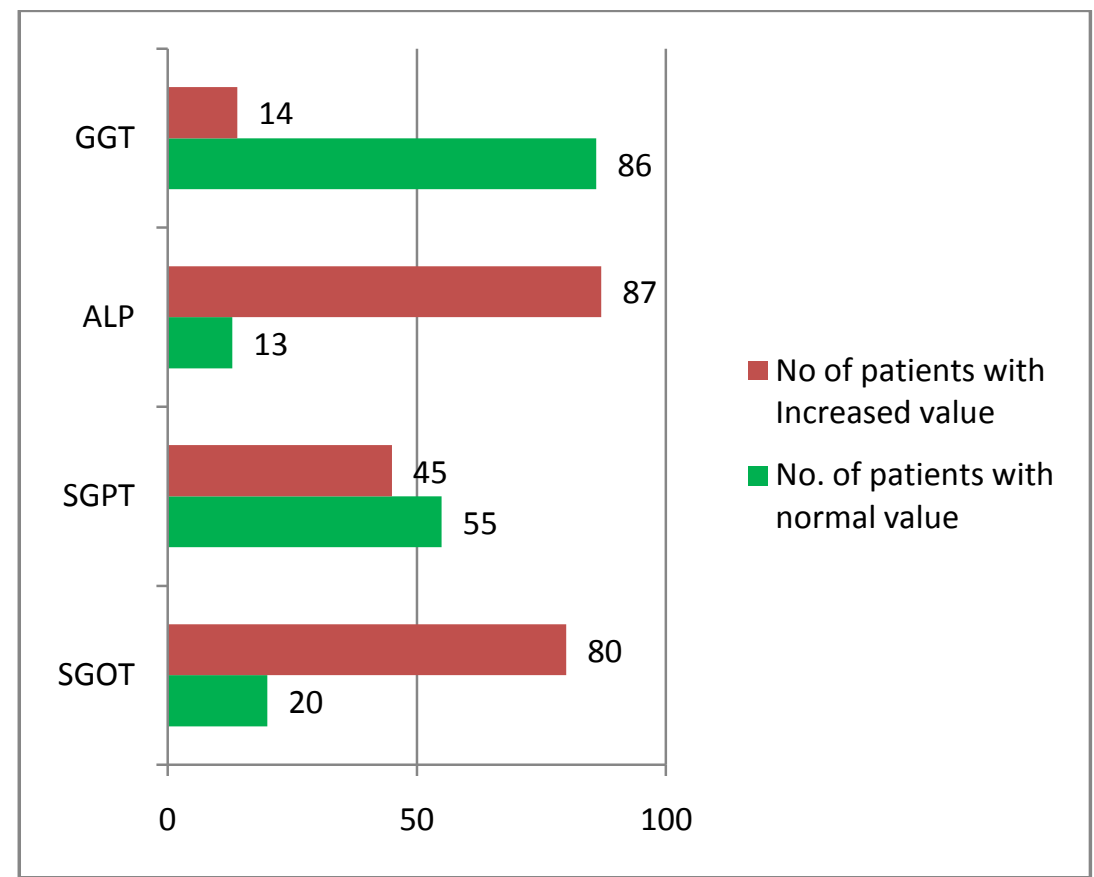

Graph 9: Liver Function Tests in thalassemia patients

Table 10: Other liver function tests

\begin{tabular}{|l|c|c|c|}
\hline & S.albumin & Serum total protein & S.Bilirubin \\
\hline Decreased & 23 & 22 & 0 \\
\hline Normal & 77 & 78 & 47 \\
\hline Increased & 0 & 0 & 53 \\
\hline
\end{tabular}

Serum albumin and serum total protein were found to be decreased in 23 and 22 patients respectively. 77 and 78 patients had normal serum albumin and serum total protein value respectively. Serum bilirubin was increased in 53 patients and normal in 47 patients. The mean and S.D. of serum albumin, serum total protein and serum bilirubin was observed to be $3.7 \pm 0.53 \mathrm{gm} \%, 7.06 \pm 0.76 \mathrm{gm} \%$ and $1.4 \pm 1.1 \mathrm{mg} \%$ respectively.

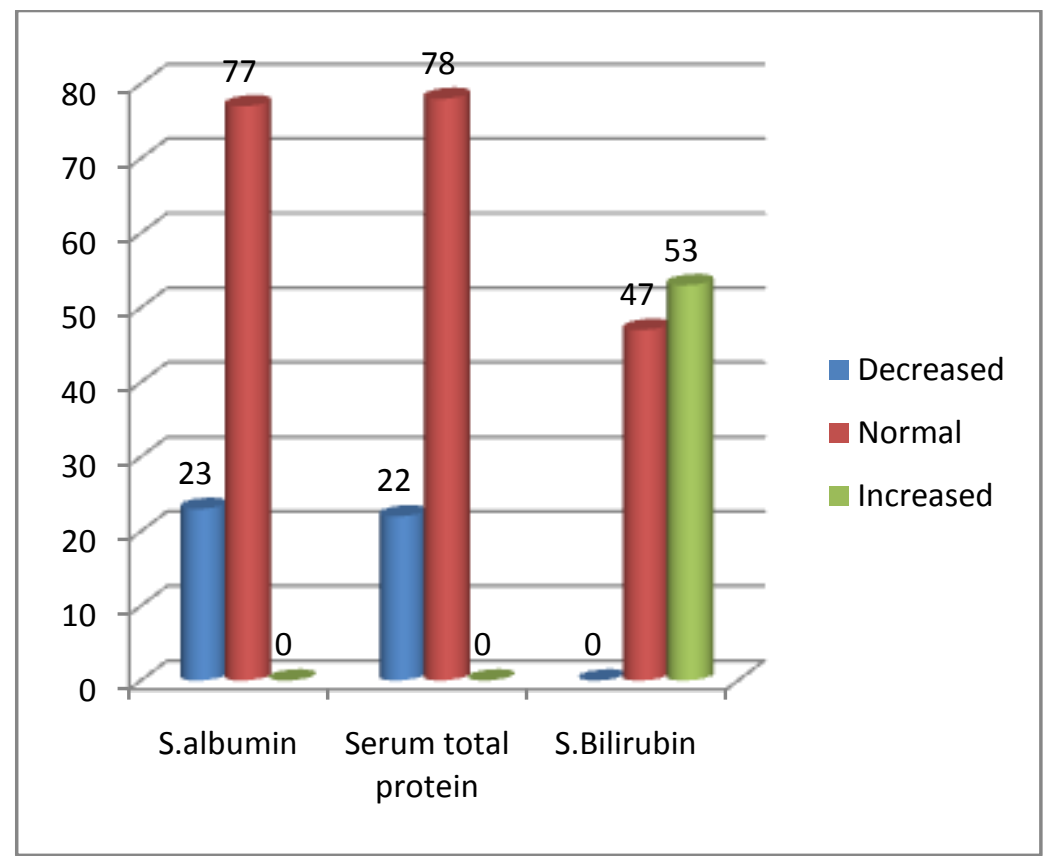

Graph 10: Other liver function tests

Table 11(a): Ferritin levels and T2*MRI in thalassemia patients 


\begin{tabular}{|l|c|c|c|}
\hline & T2* MRI Heart & T2* MRI Liver & $\begin{array}{c}\text { Ferritn levels } \\
\text { (ng/ml) }\end{array}$ \\
\hline Patient no1 & Normal & Severe siderosis & 5457.59 \\
\hline Patient no 2 & Normal & Severe siderosis & 9900.56 \\
\hline Patient no 3 & Normal & Severe siderosis & 2211.86 \\
\hline Patient no 4 & Normal & Severe siderosis & 4191.24 \\
\hline Patient no 5 & Normal & Severe siderosis & 5966.65 \\
\hline Patient no 6 & Normal & Severe siderosis & 1400.00 \\
\hline Patient no 7 & Normal & Mild siderosis & 3000.00 \\
\hline Patient no 8 & Normal & Normal & 2597.00 \\
\hline Patient no 9 & Mild & Severe siderosis & 2602.73 \\
\hline Patient no10 & Severe siderosis & Normal & 7251.86 \\
\hline Patient no 11 & Severe siderosis & Severe siderosis & 10,000 \\
\hline
\end{tabular}

Table 11(b):

\begin{tabular}{|l|c|c|}
\hline & Heart MRI & Liver MRI \\
\hline Normal & 8 & 2 \\
\hline Mild Siderosis & 1 & 1 \\
\hline Severe Siderosis & 2 & 8 \\
\hline
\end{tabular}

T2* MRI was possible for 11 patients out of which 8 had severe liver siderosis and 2 had severe heart siderosis. Liver was normal in 2 patients and heart was normal in 8 of the patients. Mild liver and heart siderosis was seen in 1 patient each. While comparing ferritin levels it was observed that iron load in these two organs was not seen until ferritin levels cross $2200 \mathrm{ng} / \mathrm{ml}$ except one case where liver siderosis of severe degree was seen at $1400 \mathrm{ng} / \mathrm{ml}$. Iron overload in heart was seen in 3 patients and their serum ferritin levels ranged from $2600-10,000 \mathrm{ng} / \mathrm{ml}$. In them liver siderosis of severe degree was noted in 2 patients. So the table indicates that higher the ferritin level, more the chances of heart and liver siderosis but levels around $1500 \mathrm{ng} / \mathrm{ml} \mathrm{may} \mathrm{also}$ affect these organs in some patients. The picture would have been more clear had all patients registered for the study undergone T2*MRI scan. But an inference can be made that serum ferritin levels around $1500 \mathrm{ng} / \mathrm{ml}$ or less may not always indicate that liver and heart are not affected by iron overload.

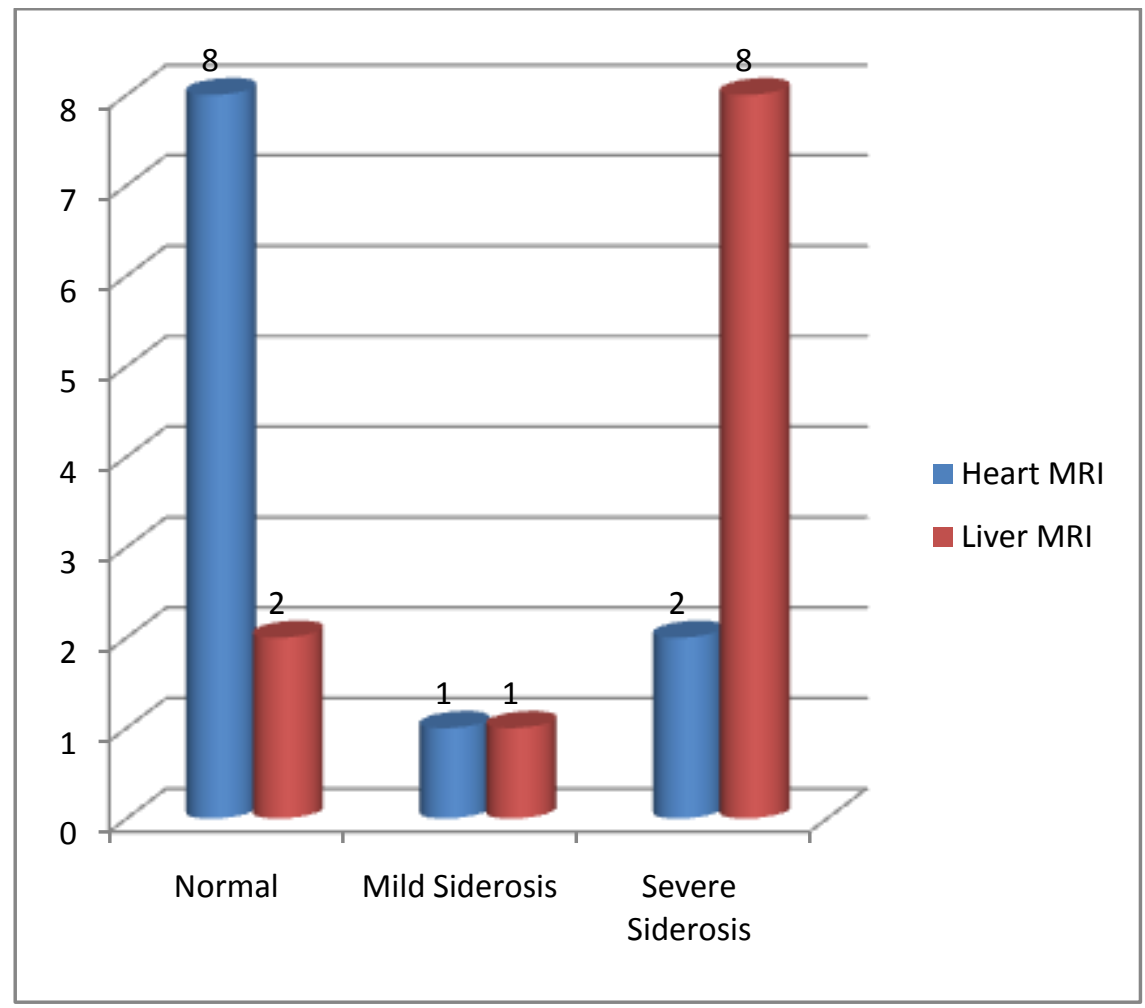

Graph 11: Ferritin levels and $T 2 *$ MRI in thalassemia patients 
Table 12: Correlation between Serum Iron \& TIBC

\begin{tabular}{|l|l|l|}
\hline & TIBC & S.Fe \\
\hline Normal & 40 & 7 \\
\hline Increased & 2 & 93 \\
\hline Decreased & 58 & 0 \\
\hline
\end{tabular}

$58 \%$ of the patients had decreased TIBC. $40 \%$ had TIBC within the normal range. Only $2 \%$ patients had increased TIBC. 93\% of the patients had increased serum iron and 7\% of the patients had normal serum iron levels. The mean and S.D. of TIBC and serum iron was calculated to be $272.8 \pm 77.7 \mu \mathrm{g} \%$ and $223.47 \pm 64.2 \mu \mathrm{g} \%$ respectively.

\section{Renal function tests in thalassemia patients}

Serum urea estimated was in the range of $15-48 \mathrm{mg} / \mathrm{dl}$ out of which only 2 patients had urea levels above $40 \mathrm{mg} / \mathrm{dl}$. Serum creatinine estimated was in the range of 0.4-0.8 $\mathrm{mg} \%$ that is within normal limits. The mean and S.D. of serum urea and creatinine was calculated to be $24.4 \pm 6.7 \mathrm{mg} \%$ and $0.56 \pm 0.12 \mathrm{mg} \%$ respectively.

\section{Blood sugar estimation in thalassemia patients}

Blood sugar levels estimated in thalassemia patients were found to be increased in 3 patients out of which 2 had diabetes mellitus. The mean and S.D. of blood sugar was calculated to be $100.5 \pm 41.9 \mathrm{mg} \%$. The ferritin levels of diabetic thalassemics were $10,000 \mathrm{ng} / \mathrm{ml}$ and $7251.86 \mathrm{ng} / \mathrm{ml}$ respectively.

Table 13: Chelation therapy and ferritin levels

\begin{tabular}{|l|c|c|}
\hline Type of chelation & No of patients & Ferritin levels(ng/ml) \\
\hline Deferiprone+Hydoxyurea & 1 & 1522.00 \\
\hline Deferoxamine+Deferiprone & 5 & 2758.19 \\
\hline Deferiprone & 62 & 3995.75 \\
\hline Deferasirox & 20 & 4188.68 \\
\hline Deferiprone+Deferasirox & 8 & 5446.13 \\
\hline Deferoxamine & 4 & 6407.00 \\
\hline
\end{tabular}

Majority (62\%) of the patients are taking deferiprone as the chelating agent. Other drugs that are included in the treatment regime are deferasirox, deferoxamine as well as hydroxyurea. But most of them are not following the treatment regimes regularly. Only interpretation from the above table is that the chelating agents will have individualised effect. Some chelating agents may suit one group of patients and others may suit other group, and this needs further observation.

Although 100\% compliance was not seen in most patients for regular blood transfusion and adequate iron chelation but individual patients who by and large could manage frequent blood transfusions and better iron chelation had higher hemoglobin levels, normal liver function tests and lower serum ferritin levels as compared to others. Overall quality of life was also observed to be better in these patients.

Higher hemoglobin level, serum ferritin $<1000 \mathrm{ng} / \mathrm{ml}$ and normal liver function tests are indicators of good prognosis as their growth, development and quality of life was observed to be better compare to patients having low hemoglobin level, abnormal liver function tests (due to either liver siderosis or hepatitis) and higher serum ferritin levels.

Clinically facial deformities-thalassemic facies, height and developmental abnormalities were observed to be minimum in patients who were better chelated and having regular blood transfusion as compare to those who were poorly chelated and irregularly transfused.

\section{Discussion}

Thalassemias are inherited disorders characterized by abnormal production of hemoglobin, associated with low hemoglobin production and excessive destruction of red blood cells. They are a heterogenous group of disorders and are considered as the most common monogenic disorder in the world. Present study was conducted to observe serological parameters in 100 thalassemia patients attending thalassemia clinic at SMGS hospital, Government Medical College, Jammu.

The present study comprised of $90 \%$ thalassemia major patients and $10 \%$ thalassemia intermedia patients. Though 6 thalassemia minor patients were registered with the thalassemia welfare society but were not included in the study as they were not attending the thalassemia clinic because of non requirement of transfusions. As thalassemia major patients require more transfusions, they are seen more in number than thalassemia intermedia.

In the study majority of the patients $(40 \%)$ were in the age group of $6-10$ years followed by $25 \%$ in the age group of $11-15$ years. $23 \%$ of the patients were above the age of 15 years. Only $12 \%$ of the patients were in 
the age group of 1-5 years. The youngest patient was 2 years old and oldest was 31 years old. The mean age was $11.85 \pm 6.3$ years. Without transfusions, majority of children with thalassemia major do not survive the first decade of life, but with the availability of blood transfusion services and setting up of thalassemia clinic, most of these children are living longer lives.

Males were more in number comprising $62 \%$ of the patients and females were $38 \%$. This is comparable with most of the studies conducted where male predominance has been seen. However, increased male presentation can be partly explained by the deep-rooted gender bias among the parents of these chronically ill children who seek medical care and are ready to spend more for their male children only.

$50 \%$ patients had splenomegaly at the time of study. Out of these 14(28\%) had mild splenomegaly, $34(68 \%)$ had moderate splenomegaly and $2(4 \%)$ had massive splenomegaly. $9 \%$ had undergone splenectomy and rest 41 patients had normal spleen. The main symptom in beta thalassemia major is severe anemia due to ineffective erythropoeisis. Increased hemolysis instigates hyperplasia of the RES, erythroid hyperplasia and extramedullary hemopoiesis. Extramedullary hemopoeisis in the spleen initiates splenomegaly. Massive splenomegaly instigates pooling and increases sequestration, resulting in cytopenias. At this stage, to improve the anemia, splenectomy is performed.

$40 \%$ of the patients have received less than 100 transfusions correlating with the fact that maximum number of patients were in the age group of 6-10 years. Thalassemia intermedia patients come for blood transfusion usually after 2-3 months except one who became transfusion dependent possibly secondary to hypersplenism. Majority of the thalassemia major patients come irregularly for transfusions due to the fact that they have to come from far flung areas and to avoid the burden of expenditure. Only $25 \%$ of the patients come regularly for transfusions that is 2-3 times per month. Some children miss their transfusion because of academic activities. Those who are regular come atleast twice a month. The groups of homozygous and heterozygous thalassemia intermedia required infrequent blood transfusions i.e. 1-2 unit/year. Four patients in both the groups required frequent blood transfusions. Three of these patients developed hypersplenism.

Blood group O+ was found to be most frequent (29\%) followed by A+ group (27\%) and B+ group (26\%). Rh negative blood groups were the least frequent comprising $5 \%$ of the total thalassemia patients in the study of which 1 patient each was included in the A-, $\mathrm{AB}$ - and $\mathrm{B}$ - group. 2 patients were having $\mathrm{O}$ - blood group.

$12 \%$ of the patients were positive for anti- hepatitis $\mathrm{C}$ antibodies and only $1 \%$ of the patient was found to be positive for hepatitis B surface antigen. In total $13 \%$ of the individuals were hepatitis positive. None of the patients was positive for HIV which could be due to low prevalence of HIV in J\&K. Professional donors and people at high risk are discouraged from donating blood in the blood bank and none of the thalassemic child has received blood from professional donors. Poly-transfusion in thalassemic patients is considered one of the major risk factors to acquire hepatitis. In this study, an association is found between the number of transfusions and hepatitis positive patients $(r=0.288$, $p$-value $=0.004)$. A gradual increase was seen in the percentage of hepatitis positive thalassaemic patients with the increase in the number of transfusions. The decrease in percentage of hepatitis $\mathrm{B}$ virus infection as compare to hepatitis $\mathrm{C}$ infection may be explained by the increasing rate of vaccination due to public awareness about the disease and inclusion of hepatitis vaccine in expanded program on immunization (E.P.I) schedule. Moreover our centre is providing regular free prophylaxis against hepatitis B vaccination. Despite of receiving screened blood for transfusion, the residual risk of acquiring a TTI depends on the safety of the donor population, the sensitivity of the screening tests used, window-period donations and other reasons, such as mutant strains.

The ferritin values ranged from 481.98 to $12,000 \mathrm{ng} / \mathrm{ml}$. The mean and S.D. of ferritin was calculated to be $4160.20 \pm 2426.53 \mathrm{ng} / \mathrm{ml}$. The ferritin levels in the patients of the present study are high as patients had undergone many transfusions but exhibit meagre compliance for chelation therapy.

TIBC is the ability of the plasma protein to bind iron and an indirect measure of transferrin levels. 58\% patients in our study had decreased total iron binding capacity. $40 \%$ had TIBC within the normal range. Only 2 patients had increased TIBC. One of them had associated increased liver function enzymes and other had associated increased alkaline phosphatase. Majority of the patients had decreased TIBC because of the decreased capacity of the available transferrin levels to bind increased levels of iron. 93\% of the patients had increased serum iron levels and 7\% of the patients had normal serum iron levels. Increased iron levels reflects the transfusion load on the patients as well as inadequate chelation therapy. The mean and S.D. of TIBC and serum iron was calculated to be $272.8 \pm 77.7 \mu \mathrm{g} \%$ and $223.47 \pm 64.2 \mu \mathrm{g} \%$ respectively

SGOT,SGPT,ALP and GGT were increased in $80,45,87$ and 14 patients respectively but significantly elevated (significant increase was considered in patients having two times increase in the upper limit of the reference range) levels of SGOT, SGPT and ALP were seen in 34, 19 and 9 patients respectively. None of these patients had significantly increased GGT values except one with GGT value of $166 \mathrm{IU} / \mathrm{L}$. The mean and S.D. of SGOT, SGPT, ALP and GGT was estimated to be $85.3 \pm 126.4 \mathrm{IU} / \mathrm{L}, 98.2 \pm 146.4 \mathrm{IU} / \mathrm{L}, 179.2+85.7 \mathrm{IU} / \mathrm{L}$ and $62.4+22.5 \mathrm{IU} / \mathrm{L}$ respectively. Liver disease associated with chronic blood transfusions in thalassemic patients is caused by hepatotropic infections or hepatic siderosis. Both factors may act either synergistically or 
independently in promoting chronic liver disease, inducing cellular damage through similar oxidative pathways. Through statistical analysis it was clear that a good correlation exists between hepatitis and SGOT $(\mathrm{r}=0.280, \mathrm{p}=0.005)$ and, hepatitis and SGPT $(\mathrm{r}=0.313, \mathrm{p}=0.002)$. Increased liver enzymes in the hepatitis negative patients could be attributed to iron overload on the liver due to chronic blood transfusions. Statistical analysis showed a good correlation between ferritin levels and ALP $(r=0.200, p=0.046)$.

Serum albumin and serum total protein were found to be decreased in $23 \%$ and $22 \%$ of the patients respectively. Serum bilirubin was increased in 53 patients and normal in 47 patients. Increase in bilirubin in thalassemia may be related to hemolytic process and confirm the existing hepatic damage. Decreased serum total protein and albumin is due to secondarily decreased synthesis of protein by the liver. Elevation of liver protein enzymes in thalassemic patients further support this view. The mean values of serum albumin, serum total protein and serum bilirubin in the present study was found to be $3.7 \pm 0.53 \mathrm{gm} \%, 7.06 \pm 0.76 \mathrm{gm} \%$ and $1.4 \pm 1.1 \mathrm{mg} \%$ respectively.

Serum urea estimated was in the range of $15-48 \mathrm{mg} / \mathrm{dl}$. Only two patients had value above $40 \mathrm{mg} / \mathrm{dl}$ and that were 47 and $48 \mathrm{mg} / \mathrm{dl}$ but their creatinine levels were within normal limits. The concentration of serum creatinine is the most widely used and commonly accepted measure of renal function in clinical medicine. Serum creatinine estimated was in the range of $0.4-0.8 \mathrm{mg} \%$. The mean and S.D. of serum urea and serum creatinine was observed to be $24.4 \pm 6.7(\mathrm{mg} / \mathrm{dl})$ and $0.56 \pm 0.12(\mathrm{mg} \%)$.

Blood sugar levels estimated in thalassemia patients and $2 \%$ of individuals were found to have diabetes mellitus. Their ferritin levels were $10,000 \mathrm{ng} / \mathrm{ml}$ and $7251.86 \mathrm{ng} / \mathrm{ml}$ respectively. The mean ferritin of non diabetic thalassemics was $4069.06 \mathrm{ng} / \mathrm{ml}$. This is in accord with the fact that diabetes in these patients is usually due to iron deposition in the pancreas leading to beta cell destruction and consequent insulin deficiency.

T2* MRI was possible for 11 patients. We observed that higher the ferritin level, more the chances of heart and liver siderosis but levels around $1500 \mathrm{ng} / \mathrm{ml}$ may also affect these organs in some patients. The picture would have been more clear had all patients registered for study undergone T2* MRI scan. But an inference can be made that serum ferritin levels around $1500 \mathrm{ng} / \mathrm{ml}$ or less may not always indicate that liver and heart are not affected by iron overload.

Majority (62\%) of the patients are taking deferiprone as the chelating agent. Other drugs that are included in the treatment regime are deferasirox, deferoxamine as well as hydroxyurea. But most of them are not following the treatment regimes regularly. The main issue in assessing the affect of any chelating agent is irregular compliance that is regular intake of chelating agent as advised is not seen in most of these patients, the reason being side effects of any particular agent and affordability. Regarding deferasirox, most of the patients use it only when they stop deferiprone or deferoxamine due to side effects. So exact effect of these chelating agents on our patients can't be predicted and assessed. This aspect requires more study in a larger group of patients where compliance is $100 \%$. Deferoxamine is the most effective chelating drug in iron overloaded multitransfused thalassemic patients. In view of cost and unacceptability of daily deferoxamine injections, combination therapy is an effective method of chelation thus increasing the compliance and cost effectiveness.

Although 100\% compliance was not seen in most patients for regular blood transfusion and adequate iron chelation but individual patients who by and large could manage frequent blood transfusion and better iron chelation had higher hemoglobin levels, normal liver function tests and lower serum ferritin levels as compared to others. Overall quality of life was also observed to be better in these patients. Higher hemoglobin level, serum ferritin $<1000 \mathrm{ng} / \mathrm{ml}$ and normal liver function tests are indicators of good prognosis as their growth, development and quality of life was observed to be better compare to patients having low hemoglobin level, abnormal liver function tests (due to either liver siderosis or hepatitis) and higher serum ferritin levels. Clinically facial deformities-thalassemic facies, height and developmental abnormalities were observed to be minimum in patients who were better chelated and having regular blood transfusion as compare to those who were poorly chelated and irregularly transfused.

\section{Conclusion}

- The registered patients of thalassemia in thalassemia day care centre are 273. Out of these 100 patients satisfied the inclusion criteria and were taken up for the study.

- There were 90 thalassemia major and 10 thalassemia intermedia patients between 2-31 years of age.

- 40 patients were in the age group of 6-10 years followed by 25 patients in the age group of 11-15 years. 23 patients were above the age of 15 years.

- The study comprised of 62 males and 38 females.

- Fifty one patients had splenomegaly at the time of study. Out of these 51 patients 14 had mild splenomegaly, 35 had moderate splenomegaly and 2 had massive splenomegaly. Nine patients had already undergone splenectomy at the time of study for various reasons especially cytopenia or hypersplenism. 
- Blood group O+ was found to be the most frequent (29\%) followed by A+ group (27\%) and B+ group (26\%). Rh negative blood groups were the least frequent comprising $5 \%$ of the total thalassemic patients in the study.

- 12 patients were positive for anti- hepatitis $\mathrm{C}$ antibodies and only one patient was found to be positive for hepatitis B surface antigen. In this study, an association is found between the number of transfusions and hepatitis positive patients $(r=0.288$, $p$-value $=0.004)$. None of the patient was HIV positive.

- A good correlation existed between hepatitis and abnormal liver function tests SGOT and SGPT.

- Regular blood transfusion is experienced in only about $25 \%$ of the patients and their pre transfusion hemoglobin level was between 9-10 gm/dl. Majority of the patients don't receive regular blood transfusion because of various factors like distance, hilly areas, non-availability of transport facilities, and socioeconomic status.

- The ferritin values ranged from 481.98 to $12,000 \mathrm{ng} / \mathrm{ml}$. The mean ferritin was calculated to be $4160 \pm 2426$ $\mathrm{ng} / \mathrm{ml}$.

- SGOT, SGPT, ALP and GGT were increased in 80,45,87 and 14 patients respectively but significant increase was considered in patients having two times increase in the upper limit of the reference range. Significantly elevated levels of SGOT, SGPT and ALP were seen in 34, 19 and 9 patients respectively. None of these patients had significantly increased GGT values except one with GGT value of $166 \mathrm{IU} / \mathrm{L}$.

- Increased liver enzymes in the hepatitis negative patients could be attributed to iron overload on the liver due to chronic blood transfusions and inadequate chelation. Statistical analysis showed a good correlation between ferritin levels and ALP $(\mathrm{r}=0.200, \mathrm{p}=0.046)$.

- Blood sugar levels were estimated and two patients were found to have diabetes mellitus. Their ferritin levels were $10,000 \mathrm{ng} / \mathrm{ml}$ and $7251.86 \mathrm{ng} / \mathrm{ml}$ respectively. The mean ferritin of non diabetic thalassemics was $4069.06 \mathrm{ng} / \mathrm{ml}$. This is in accord with the fact that diabetes in these patients is usually due to iron deposition in the pancreas leading to beta cell destruction and consequent insulin deficiency.

- T2* MRI was possible in only 11 patients. It didn't correlate well with serum ferritin levels. In other words serum ferritin levels may not indicate liver and heart siderosis in all the patients. Hence, the need of T2* MRI in these patients is must atleast once a year.

- Clinically facial deformities like thalassemic facies, height and developmental abnormalities were minimum in patients who were better chelated and having regular blood transfusion as compare to those who were poorly chelated and irregularly transfused.

- Majority of the patients are taking deferiprone as the chelating agent as it is provided free of cost by the thalassemia centre. Other drugs that are included in the treatment regime are deferasirox, deferoxamine as well as hydroxyurea, but most of them are not following the treatment regimes regularly. Compliance is not $100 \%$.

- Higher hemoglobin level, serum ferritin $<1000 \mathrm{ng} / \mathrm{ml}$, normal liver function tests and, normal liver and cardiac status are indicators of good prognosis.

100 thalassemia patients out of 273 registered patients were included in the study comprising of 90 thalassemia major and 10 thalassemia intermedia patients. Regular and safe blood transfusion (pre transfusion hemoglobin level greater than $10 \mathrm{gm} / \mathrm{dl}$ ), effective iron chelating agents and controlling ferritin levels are most important factors for preventing morbidity and mortality, and assuring a good quality and prolonged life in these patients. Serum ferritin may not always indicate cardiac and liver siderosis. Hence T2*MRI is indicated in these patients once a year. Prophylaxis against hepatotropic viruses are must to prevent hepatitis and other complications. Safe blood transfusion means proper facility of screening blood donors especially NAT testing to prevent transmission of hepatotropic viruses and HIV viruses during window period. In addition to these a regular follow up and assessment of endocrine functions is necessary in assuring normal pubertal development and complication free disease. Higher hemoglobin level, serum ferritin $<1000 \mathrm{ng} / \mathrm{ml}$, normal liver function tests, normal liver and cardiac status are indicators of good prognosis.

Finally the most important message in this study is that proper awareness and education about the disease is minimal which is indicated by the fact that only 100 patients out of 273 attend the centre either once a month or once in two to three months. Rest of the patients were highly irregular or didn't come at all. Therefore health care personnel in general and society in particular need to do much hard work especially reaching to patients residence and convincing them about regular follow up at the thalassemia day care centre. At the same time screening camps at school level is recommended to identify cases especially thalassemia trait and further counselling as desired should be initiated. Civil society can also contribute in coming out openly and offer financial and other support of these patients as it is not possible only at government level. 


\section{Bibliography}

[1]. Adil A, Sobani ZA, Jabbar A, Adil SN, Awan S.. Endocrine complications in patients of beta thalassemia major in a tertiary care hospital in Pakistan. J Pak Med Assoc 2012; 62(3): 307-10

[2]. Adlekha S, Chadha T, Jaiswal RM, Singla A. Screening of $\beta$-thalassaemia trait by means of red cell indices and derived formulae. Med J DY Patil Univ 2013; 6: 71-74

[3]. Al Haddad RM. Molecular, biochemical and hematological investigations of beta thalassemic children in Gaza governorate. Thesis submitted to islamic university, Gaza 2012. Available at : http://library.iugaza.edu.ps/thesis/106956.pdf Accessed on January, 2016

[4]. Ali D, Mehran K, Moghaddam AG. Comparative evaluation of renal findings in beta-thalassemia major and intermedia. Saudi J Kidney Dis Transpl 2008; 19(2): 206-09

[5]. Al-Kataan MA, Al-Rasheed SM, Ahmed FA. Serum iron status in beta-thalassemic patients with clinical signs of iron overload. Tikrit Med J 2009; 15(1): 9-12

[6]. Al-Samarrai AH, Adaay MH, Al-Tikriti KA, Al-Anzy MM. Evaluation of some essential element levels in thalassemia major patients in Mosul district, Iraq. Saudi Med J 2008; 29(1): 94-97

[7]. Al-Wataify AS. Growth Retardation among multi-transfused thalassemic patients in thalassemia center in Babylon governorate. MJB 2014; 9(4): doi:1812-156X-9-4

[8]. Al-Wtaify ASM, Al-Shujairi GSH. Prevalence of diabetes and hypocalcemia among thalassemic patients in thalassemia center in Babylon governorate. MJB 2014; 6(3): doi:1812-156X-6-3

[9]. Aminianfar M, Saidi AA, Fallah A, Barghi A. Prevalence of hepatitis B and C among hemodialysis and thalassemic patients in a special medical center in east Tehran in 2011. Afr J Microbiol Res 2012; 6(24): 5285-87

[10]. Ansari SH, Shamsi TS, Khan MT, Perveen K, Farzana T, Erum S, et al. Seropositivity of hepatitis C, hepatitis B and HIV in chronically transfused $\beta$-thalassaemia major patients. J Coll Physicians Surg Pak 2012; 22(9): 610-11

[11]. Arica V, Arica S, Ozer C, Cevik M. Serum lipid values in children with beta thalassemia major. Pediatr Therapeut 2012; 2: 130

[12]. Arshad MS, Hyder SN. Evidence of abnormal left ventricular function in patients with thalassemia major: an echocardiography based study. J Ayub Med Coll Abbottabad 2009; 21(2): 37-41

[13]. Ataei B, Hashemipour M, Kassaian N, Hassannejad R, Nokhodian Z, Adibi P. Prevalence of anti HCV infection in patients with beta-thalassemia in Isfahan-Iran. Int J Prev Med 2012; 3(1): 118-23

[14]. Attia MMA, Sayed AM, Ibrahim FA, Mohammed AS, El-Alfy MS. Effects of antioxidant vitamins on the oxidant/antioxidant status and liver function in homozygous beta thalassemia. Romanian J Biophys 2011; 21(2): 93-106

[15]. Azarkeivan A, Hashemieh M, Akhlaghpoor S, Shirkavand A, Yaseri M, Sheibani K. Relation between serum ferritin and liver and heart MRI T2* in beta thalassaemia major patients. EMJH 2013; 19(8): 727-32

[16]. Baker N, Alnakashabandi A, Alsaqy AH, Alrabaty A. Growth pattern and sexual maturation rate in $\beta$-thalassemia major patients from thalassemia center Erbil. Iraq Postgrad Med J 2013; 12(1): 40-44

[17]. Balgir RS, Mishra RK, Murmu B. Clinical and hematological profile of hemoglobinopathies in two tribal communities of Sundargarh district in Orissa, India. Int J Hum Genet 2003; 3(4): 209-16

[18]. Bastawy SA, Abd El Wahab MB, Fahmy MA. Antioxidant and hematological study among Egyptian thalassemic children. JMSCR 2013; 1(4): 165-71

[19]. Belhoul KM, Bakir ML, Saned MS, Kadhim AM, Musallam KM, Taher AT. Serum ferritin levels and endocrinopathy in medically treated patients with $\beta$ thalassemia major. Ann Hematol 2012; 91(7): 1107-14

[20]. Belsare V, Belsare H, Lambe S. Study of biochemical parameters in beta thalassemia major patients. IJRTSAT 2015; 13(3): 526-30

[21]. Berak M, Mirzarahimi M, Habibzadeh H. Endocrine complications in patients of beta thalassemia major in Ali Asghar hospital in Ardabil. Unpublished PhD.Thesis, Medical University of Ardabil, 2004

[22]. Bharat V, Gupta S, Gupta R. Detection of carriers for $\beta$-thalassemia: A case study of Jammu (J\&K). Orient J Chem 2010; 26(1): 199-06

[23]. Bhukhanvala D, Seliya V, Shah A, Gupte S. Study of parents of $\beta$-thalassemia major children to determine cutoff values of hematological parameters for diagnosis of $\beta$-thalassemia trait and assessment of anemia in them. Ind J Med Sci 2013; 67: 117-22

[24]. Borgna-Pignatti C, Galanello R. Thalassemia and related disorders: quantitative disorders of hemoglobin synthesis. In (eds): Greer JP, Foerster J, Rodgers GM, et al. Wintrobe's Clinical Hematology, vol 1, $12^{\text {th }}$ edt. Lippincott Williams and Wilkins, China; 2009.pp. 1084-132

[25]. Briggs C, Bain BJ. Basic hematological techniques. In (eds): Bain BJ, Bates I, Laffan MA, et al. Dacie and Lewis Practical hematology, $11^{\text {th }}$ edt. Churchill livingstone, Elsevier, China; 2012. pp. 23-56

[26]. Ceci A, Mangiarini L, Felisi M, Bartoloni F, Ciancio A, Capra M, et al. The management of iron chelation therapy: preliminary data from a national registry of thalassaemic patients. Available at: http://dx.doi.org/10.1155/2011/435683 Accessed on: January, 2016

[27]. Choudhry VP, Pattit P, Saxena A, Malaviya AN. Deferiprone, efficacy and safety. Ind J Pediatr 2004; 71(3): 213-16

[28]. Cunningham MJ, Macklin EA, Neufeld EJ, Cohen AR. Complications of beta thalassemia major in North America. Blood 2004; 104(1): 34-39

[29]. Din G, Malik S, Ali I, Ahmed S, Dasti JI. Prevalence of hepatitis C virus infection among thalassemia patients: a perspective from a multi-ethnic population of Pakistan. Asian Pac J Trop Biomed 2014; 7(1): 127-33

[30]. Eghbali A, Taherahmadi H, Shahbazi M, Bagheri B , Ebrahimi L Association between serum ferritin level, cardiac and hepatic T2star MRI in patients with major $\beta$-thalassemia. Iran J Ped Hematol Oncol 2014; 4(1): 17-21

[31]. El-Hazmi MA, Warsy AS, Al-Fawaz 1. Iron-endocrine pattern in patients with beta-thalassaemia. J Trop Pediatr 1994; 40(4): 21924

[32]. Faruqi A, Ahmed ST, Ahmed F. Association of serum ferritin levels with haematological parameters in thalassaemia major patients JRMC 2014; 18(2): 219-21

[33]. Gomber S, Saxena R, Madan N. Comparative efficacy of desferrioxamine, deferiprone and in combination on iron chelation in thalassemic children. Indian Pediatr 2004; 41: 21-27

[34]. Goyal JP, Hapani PT, Gagiya H. Prevalence of human immunodeficiency virus and hepatitis B among multi-transfused thalassemia children. J Appl Hematol 2015; 6: 70-73

[35]. Hamed EA, ElMelegy NT. Renal functions in pediatric patients with beta-thalassemia major: relation to chelation therapy: original prospective study. Ital J Pediatr 2010; 36: 39

[36]. Hashemizadeh H, Noori R, Kolagari SH. Assessment hepatomegaly and liver enzymes in 100 patients with beta thalassemia major in Mashhad, Iran. Iran J Ped Hematol Oncol 2012; 2(4): 171-77

[37]. Kawthalkar SM. Anemias due to excessive red cell destruction. Essentials of haematology, $2^{\text {nd }}$ edt. Jaypee brothers medical publishers, India; 2013. pp. 141-71 
[38]. Khan JA, Qari MH, Al-Sharif NH. Hematological parameters and elements level in three different groups of thalassemia major. Bahrain Med Bull 2004; 26(2): 1-7

[39]. Kunjwani SS, Khan ZH. Awareness and screening of $\beta$ thalassemia trait in sindhi community. Ind J Applied Res 2013; 3(7): 31-33

[40]. Laksmitawati DR, Handayani S, Udyaningsih-Freisleben SK, Kurniati V, Adhiyanto C, Hidayat J, et al. Iron status and oxidative stress in beta-thalassemia patients in Jakarta. Biofactors 2003; 19: 53-62

[41]. Lau YL, Chow CB, Lee AC, Ng KW, Lim WL, Chan CF, et al. Hepatitis C virus antibody in multiply transfused Chinese with thalassaemia major. Bone Marrow Transplant 1993;12(1): 26-28

[42]. Mahadik C, Kapadia C, Yagnik H, Sukumaran PK, Merchant S. One tube osmotic fragility as a useful screening test for thalassemia carriers- A field experience. Indian J Hematol 1986; 4: 62-64

[43]. Maheshwari M, Arora S, Kabra M, Menon PSN. Carrier screening and prenatal diagnosis of beta-thalassemia. Indian Pediatr 1999; 36(11): 1119-25

[44]. Mallik S, Chatterjee C, Mandal PK, Sardar JC, Ghosh P, Manna N. Expenditure to treat thalassemia: An experience at a tertiary care hospital in India. Iran J Public Health 2010; 39(1): 78-84

[45]. Mankad GP, Mankad B, Singh SP. A study of serological and hematological parameters in thalassemic patients of Gujarat, western India. IOSR-JDMS 2013; 9(5): 52-55

[46]. Mansi K, Aburjai T, AlBashtawy M, Abdel-Dayem M. Biochemical factors relevant to kidney functions among Jordanian children with beta-thalassemia major treated with deferoxamine. Int J Med Med Sci 2013; 5(8): 374-79

[47]. Mansi KM, Aburjai TA. Lipid profile in Jordanian children with B-thalassemia major. Int J Hematol Oncol 2008;18(2): 93-98

[48]. Mansouritarghabeh $\mathrm{H}$, Badie Z.Transfusion-transmitted viruses in individuals with $\beta$ thalassemia major at northeastern Iran, a retrospective sero-epidemiological survey. IJBC 2008; 1(1): 1-4

[49]. Mehdi SR, Al Dahmash BA. A comparative study of hematological parameters of $\alpha$ and $\beta$ thalassemias in a high prevalence zone: Saudi Arabia. Indian J Hum Genet 2011; 17(3): 207-11

[50]. Mirbehbahani NB, Rashidbaghan A, Mazji M, Behnampour N. National approach to premarital diagnosis of trait thalassemia and silent carriers. Int J Clin Med 2013; 4(2): 91-95

[51]. Mohammad II, Al-Doski FS. Assessment of liver functions in thalassaemia. Tikrit J Pharmaceutical Sci 2012; 8(1): 87-95

[52]. Mula-Abed WA, Al Hashmi AH, Al Muslahi M, Al Muslahi H, Al Lamki M. Prevalence of endocrinopathies in patients with betathalassaemia major - a cross-sectional study in Oman. Oman Med J 2008; 23(4): 257-62

[53]. Munir B, Iqbal T, Jamil A, Muhammad F. Effect of $\beta$ thalassemia on hematological and biochemical profiles of female Patients. Pak J life Soc Sci 2013; 11(1): 25-28

[54]. Napoli N, Carmina E, Bucchieri S, Sferrazza C, Rini GB, Di Fede G. Low serum levels of 25-hydroxy vitamin D in adults affected by thalassemia major or intermedia. Bone 2006; 38(6): 888-92

[55]. Niazi M,Tahir M, e Raziq F, Hameed A. Usefulness of red cell indices in differentiating microcytic hypochromic anemias. Gomal J Med Sci 2010; 8(2): 125-29

[56]. Nillakupt K, Nathalang O, Arnutti P, Jindadamrongwech S, Boonsiri T, Panichkul S, et al. Prevalence and hematological parameters of thalassemia in Tha Kradarn subdistrict Chachoengsao Province, Thailand J Med Assoc Thai 2012; 95(5): 124-32

[57]. Oza T, Agrawat A, Dhruva DG, Oza HV. A study of prevalence of HIV, HBsAg and HCV in thalassemia major children. NJIRM 2012; 3(4): 114-17

[58]. Palit S, Bhuiyan RH, Aklima J, Emran TB, Dash R. A study of the prevalence of thalassemia and its correlation with liver function test in different age and sex group in the Chittagong district of Bangladesh. J Basic Clin Pharma 2012; 3(4): 352-57

[59]. Patil VW, Mujawar SA. Defeciency of folic acid, vitamin B12 and their correlation with ferritin in childhood $\beta$ thalassemia major. Curr Pediatr Res 2010; 14(2): 111-14

[60]. Sadeghi-Bojd S, Hashemi M, Naderi M, Shikhani S. Kidney function tests in children with beta-thalassemia minor in Zahedan, southeast of Iran. Iran J Kidney Dis 2011; 5( 3): 201-03

[61]. Shah N, Mishra A, Chauhan D, Vora C, Shah NR. Study on effectiveness of transfusion program in thalassemia major patients receiving multiple blood transfusions at a transfusion centre in western India. Asian J Transfus Sci 2010; 4(2): 94-98

[62]. Shams S, Ashtiani MTH, Monajemzadeh M, Koochakzadeh L, Irani H, Jafari F, et al. Evaluation of serum insulin, glucose, lipid profile and liver in $\beta$ thalassemia major patients and their correlation with iron overload. Lab Medicine 2010; 41(8): 486-89

[63]. Shanthi G, Balasubramanyam D, Srinivasan R. Studies on the haematological aspects of beta ( $\beta$ ) thalassemia in Tamilnadu. RJPBCS 2013; 4(3): 784-90

[64]. Sharaf KhH, Al-Anzy MMY, Mustaffa NG. Certain hematological values of the $\beta$-thalassemia major among Mosul population. Tikrit Journal of Pure Science 2006; 11(1): 1-6

[65]. Singh T. Hemolytic Anemias. Atlas and Text of hematology, $2^{\text {nd }}$ ed. Avichal publishing company, India; 2011. pp. 57-99.

[66]. Soliman A, Yassin M, Al Yafei F, Al-Naimil L, Almarri N, Sabt A, Sanctis VD. Longitudinal study on liver functions in patients with thalassemia major before and after deferasirox (DFX) therapy. Mediterr J Hematol Infect Dis 2014; 6(1): e2014025

[67]. Sultan S, Irfan SM, Kaker JU, Zeeshan R, Kidwai A. Zinc status and its correlation with basic parameters in transfusion dependent thalassemic patients: a pakistani perspective. IJBC 2014; 6(3): 113-18

[68]. Suvarna J, Ingle H, Deshmukh CT. Insulin resistance and beta cell function in chronically transfused patients of thalassemia major. Indian Pediatr 2006; 43(5): 393-400

[69]. Talsania S, Talsania N, Nayak H. A cross sectional study of thalassemia in Ahmedabad city, Gujarat. Healthline 2011; 2(1): 48-51

[70]. Tritipsombut J, Sanchaisuriya K, Fucharoen S, Fucharoen G, Siriratmanawong N, Pinmuangngam C, et al. Hemoglobin profiles and hematological features of thalassemic newborns- Application to screening of $\alpha$-thalassemia 1 and hemoglobin E. Arch Pathol Lab Med 2008; 132: 1739-45

[71]. Tyagi S, Kabra M, Tandon N, Saxena R, Pati HP, Choudhary VP. Clinico-hematological profile of thalassemia intermedia patients. Int J Hum Genet 2003; 3(4): 251-58

[72]. Vehapoglu A, Ozgurhan G, Demir AD, Uzuner S, Nursoy MA, Turkmeen S, et al. Hematological indices for differential diagnosis of $\beta$ thalassemia trait and iron deficiency anemia. Available at: http://dx.doi.org/10-1155/2014/576738 Accessed on: January, 2016

[73]. Verma IC, Choudhary VP, Jain PK. Prevention of thalassemia: A necessity in India. Indian J Pediatr 1992; 59(6): 649-54

[74]. Verma P, Singh S, Krishna A, Ali W, Tiwari S. Prevalence of haemoglobin variants, ABO and rhesus blood groups in northern Uttar Pradesh, India. Biomed Res 2013; 24 (3): 377-82

[75]. Wanachiwanawin W, Luengrojanakul P, Sirangkapracha P, Leowattana W, Fucharoen S. Prevalence and clinical significance of hepatitis C Virus infection in Thai patients with thalassemia. Int J Hematol 2003; 78(4): 374-78.

[76]. Waseem F, Khemomal KA, Sajid R. Antioxidant status in beta thalassemia major: a single-center study. Indian J Pathol Microbol 2011; 54(4): 761-63. 
[77]. Weatherall DJ. The thalassemias: Disorder of globin synthesis. In (eds): Kaushansky K, Lichtman MA, Beutler E, et al. Williams Hematology, $8^{\text {th }}$ edt. McGraw Hill, China; 2010. pp. 675-707.

[78]. Weatherall DJ, Clegg JB. Thalassemia is a global health problem. Nat Med 1996; 2(8): 847-49.

[79]. Wirawan R, Setiawan S, Gatot D. Peripheral blood and hemoglobin electrophoresis pattern in beta thalassemia major patients receiving repeated blood transfusion. Med J Indones 2004; 13(1): 8-16.

[80]. Wirawan R, Setiawan S, Kusnandar S, Munthe BG. Diabetes mellitus in B-thalassemia major patients. Med J Indones 2003; 12(2): 87-93.

[81]. Yagnik H. Post councelling follow up of thalassemia in high risk communities. Indian Paediatr 1997; 34(12): 1115-18.

[82]. Yaish HM. Thalassemia. Available at: http://www.emedicine.com/PED/topic2229.htm. Accessed on: December, 2015.

[83]. Yin XL, Wu ZK, He YY, Zhou TH, Zhou YL, Zhang XH. Treatment and complications of thalassemia major in Guangxi, Southern China. Pediatr Blood Cancer 2011; 57(7): 1174-78

[84]. Younus ZM, Alhially YAH, Bashi AYD. Evaluation of conventional renal function tests in $\beta$-thalassemia major patients in Nineveh province. Tikrit J Pharmaceutical Sci 2012; 8(1): 6-14.

[85]. Yousafzai YM, Khan S, Raziq F. $\beta$-thalassemia trait: Hematological parameters. J Ayub Med Coll Abbottabad 2010; 22(4): 84-86. 